\title{
Effect of Aging on the Microstructure and Mechanical Properties of 1460 Alloy
}

\author{
Juan Ma $\cdot$ De-Sheng Yan $\cdot$ Li-Jian Rong $\cdot$ Yi-Yi Li
}

Received: 15 May 2014/Revised: 4 September 2014/Published online: 31 January 2015

(C) The Chinese Society for Metals and Springer-Verlag Berlin Heidelberg 2015

\begin{abstract}
Effects of the aging temperature on the hardening response, the tensile properties and the precipitate microstructure evolution of 1460 alloy were studied in this work. It was found that $\mathrm{Al}_{3}(\mathrm{Sc}, \mathrm{Zr})$ and $\delta^{\prime}\left(\mathrm{Al}_{3} \mathrm{Li}\right)$ phases were precipitated from the matrix at the very early aging stage, while the precipitation of $\mathrm{T} 1\left(\mathrm{Al}_{2} \mathrm{CuLi}\right)$ and $\theta^{\prime}\left(\mathrm{Al}_{2} \mathrm{Cu}\right)$ was much slower than that of the $\delta^{\prime}$ phase. When aging at higher temperature $\left(160\right.$ and $\left.190{ }^{\circ} \mathrm{C}\right)$, the $\delta^{\prime}$, T1 and $\theta^{\prime}$ phases tended to form simultaneously and grow up very quickly. Conversely, the $\delta^{\prime}$ and $\theta^{\prime \prime}\left(\mathrm{Al}_{2} \mathrm{Cu}\right)$ phases were precipitated separately and more dispersive at lower aging temperature $\left(130{ }^{\circ} \mathrm{C}\right)$. Taken together, the alloy aged at $160{ }^{\circ} \mathrm{C}$ exhibited improved mechanical properties owing to the uniform dispersion of the fine $\mathrm{T} 1$ precipitates.
\end{abstract}

KEY WORDS: Al-Li alloy; Precipitate; Precipitation hardening process; Mechanical property

\section{Introduction}

High-specific strength Al-Li alloys, which is a result of the combination of low-density lithium and fine precipitation strengthening obtained from artificial aging [1, 2], have been regarded as competitive structural materials for aerospace and airplane industries [3]. Strengthening phases of $\delta^{\prime}\left(\mathrm{Al}_{3} \mathrm{Li}\right), \mathrm{T} 1\left(\mathrm{Al}_{2} \mathrm{CuLi}\right)$ and $\theta^{\prime}\left(\mathrm{Al}_{2} \mathrm{Cu}\right)$ are reported to form in these alloys when they are subjected to artificial aging [4]. It has been reported that the general strength is attributed to the presence of a large amount of coherent, ordered $\delta^{\prime}$ precipitates in $\mathrm{Al}-\mathrm{Li}$ alloys [5]. The $\delta^{\prime}, \mathrm{Al}_{3} \mathrm{Zr}$ $\left(\beta^{\prime}\right)$ and $\mathrm{Al}_{3}(\mathrm{Sc}, \mathrm{Zr})$ phases have the $\mathrm{L1}_{2}$ superlattice structure. In addition, studies have demonstrated that the $\beta^{\prime}$ and $\mathrm{Al}_{3}(\mathrm{Sc}, \mathrm{Zr}$ ) phases not only have a structure strengthening effect but also an age hardening effect $[6,7]$.

Available online at http://link.springer.com/journal/40195

J. Ma · D.-S. Yan · L.-J. Rong $(\bowtie) \cdot$ Y.-Y. Li

Institute of Metal Research, Chinese Academy of Sciences,

Shenyang 110016, China

e-mail: ljrong@imr.ac.cn
T1 precipitates with high aspect ratio platelets forming in the aluminum $\{111\}$ planes, which are considered as the major strengthening factor in the aged $\mathrm{Al}-\mathrm{Cu}-\mathrm{Li}$ alloys [8]. Investigation of $\mathrm{Al}-\mathrm{Li}-\mathrm{Cu}-(\mathrm{Ag})-(\mathrm{Mg})$ has revealed that $\mathrm{Mg}$ and $\mathrm{Ag}$ are partitioned inside the $\mathrm{T} 1$ phase and help in the formation of $\mathrm{T} 1$ [9]. $\theta^{\prime}\left(\mathrm{Al}_{2} \mathrm{Cu}\right)$ is believed not to play a dominant role in the strength of the $\mathrm{Al}-\mathrm{Cu}-\mathrm{Li}$ alloy because of its relatively small amount in the ternary system, by contrast, it is essential to increase the peak strength in the $\mathrm{Al}-\mathrm{Cu}$ binary alloys [10].

The above-mentioned precipitates are generated by the decomposition reactions which are very sensitive to the age conditions. It has been known that the typical aging temperature of Al-Li alloys is in the range of $150-190{ }^{\circ} \mathrm{C}$, and the aging process in the temperature range has been investigated by many researchers [11]. However, the main strengthening phase $\delta^{\prime}$ is precipitated readily below $150{ }^{\circ} \mathrm{C}$ and even at room temperature $[12,13]$. In order to enhance the mechanical properties of $\mathrm{Al}-\mathrm{Li}$ alloys, double-aging treatment referring to a sequence of heat treatments at two different temperatures was proposed. For example, the tensile properties of 1460 alloy could be enhanced when it was aged at $130{ }^{\circ} \mathrm{C}$ for $20 \mathrm{~h}$ and thereafter heated to 
$160{ }^{\circ} \mathrm{C}$ for about $16 \mathrm{~h}[14,15]$. It is noteworthy that the aging temperature is below the conventional aging temperature range during the double-aging treatment [16]. However, the effect of lower aging temperature on the microstructure and mechanical properties of the $\mathrm{Al}-\mathrm{Li}$ alloys has rarely been studied. In the previous study [17], we have discussed the effect of Sc additions on the aging behavior of 1460 alloy at $190{ }^{\circ} \mathrm{C}$. In order to optimize the aging process and deepen the understanding of the aging behavior of 1460 alloy, effects of the aging temperature (130, 160 and $190{ }^{\circ} \mathrm{C}$ ) on the microstructure and mechanical properties of 1460 alloy were studied in this work.

\section{Experimental}

The pure blanks of $\mathrm{Al}, \mathrm{Li}$ and $\mathrm{Cu}$ and the binary intermediate alloys $\mathrm{Al}$ of $\mathrm{Sc}, \mathrm{Zr}$ and $\mathrm{Ce}$ together were melted under the Ar atmosphere to produce a final ingot. The composition (in wt\%) of the ingot is: $3.06 \mathrm{Cu}, 2.04 \mathrm{Li}, 0.09$ $\mathrm{Zr}, 0.11 \mathrm{Sc}, 0.07 \mathrm{Ce}, 0.13 \mathrm{Fe}, 0.08 \mathrm{Si}$ and balance of $\mathrm{Al}$.

The cast ingot was homogenized at $500{ }^{\circ} \mathrm{C}$ for $24 \mathrm{~h}$ and cooled by forced air. Then, the ingot was deformed by extrusion, hot-rolling and cold-rolling. Finally, the sheets in about $2 \mathrm{~mm}$ thickness were prepared.

The cold-rolled sheets were subjected to solid solution treatment at $540{ }^{\circ} \mathrm{C}$ for $1 \mathrm{~h}$, and then water quenched to room temperature. The samples cut from the sheets were aged at 130,160 and $190{ }^{\circ} \mathrm{C}$ for various time and then subjected to the microhardness measurements and the tensile tests. The tensile tests were carried out on a Shimadzu Autograph Dcs-10T electronic universal testing machine at room temperature with a strain rate of $1.5 \times 10^{-3} \mathrm{~s}^{-1}$. Microhardness was measured by a Micromet 5103 hardness tester using $9.8 \mathrm{~N}$ load on the surfaces perpendicular to the rolling direction. The foils for TEM (FEI Tecnai G220 TEM) observation were electropolished in a solution with $70 \%$ methanol and $30 \%$ nitric acid.

\section{Results and Discussion}

\subsection{Age Hardening Behavior}

Figure 1 shows the age hardening curves which correspond to different temperatures of 130,160 and $190{ }^{\circ} \mathrm{C}$. It is clear that peak aging occurs earlier when the aging temperature is higher. Aging at 160 and $190{ }^{\circ} \mathrm{C}$, microhardness of the sample goes up rapidly during the initial stage and keeps increasing until it reaches the peak value at 40 and $10 \mathrm{~h}$, respectively. However, the age hardening curve is

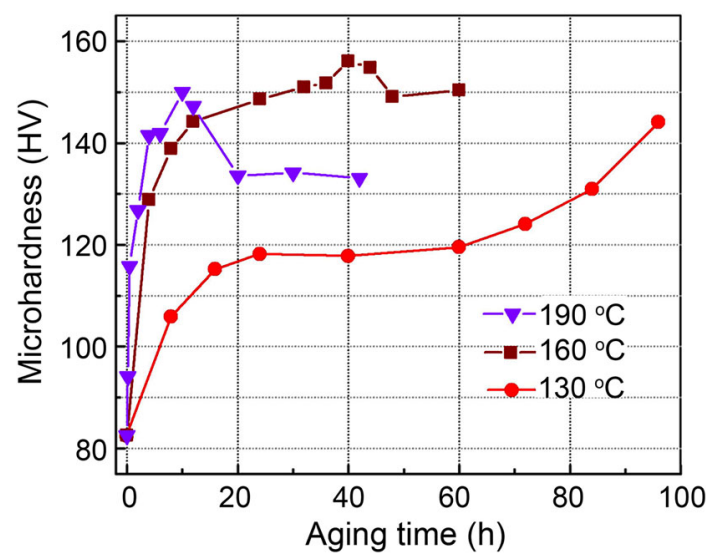

Fig. 1 Age hardening curves for 1460 alloy aged at 130, 160 and $190{ }^{\circ} \mathrm{C}$

characterized by three stages for the samples aged at $130{ }^{\circ} \mathrm{C}$ : (1) a rapid increase stage in hardness; (2) a transition stage during which the microhardness remains almost unchanged, and (3) then a gradual increase stage. It is worthwhile to notice that the increasing rate of the microhardness is far slower as the aging temperature drops to $130{ }^{\circ} \mathrm{C}$, indicating that the precipitation process is different from those of both aging at 160 and $190{ }^{\circ} \mathrm{C}$. According to the trend of the three curves, it can be concluded that the higher temperature would accelerate the age hardening process.

\subsection{Tensile Properties}

The results of tensile test of the samples aged at 190 and $160{ }^{\circ} \mathrm{C}$ are presented in Fig. 2. Figure 2a shows the tensile strength of the alloy aged at $190{ }^{\circ} \mathrm{C}$ for different time, which showing a two-stage increase: A rapid increase from $30 \mathrm{~min}$ to $4 \mathrm{~h}$ and a gradual increase from 4 to $10 \mathrm{~h}$, while the elongation decreases with aging time. In the case of aging at $160{ }^{\circ} \mathrm{C}$; however, the tensile strength exhibits a delayed two-stage increase, while the elongation decreases with aging time within $60 \mathrm{~h}$ and then displays a minor increase with further aging (Fig. 2b). According to Fig. 2, a peak tensile strength can be obtained when the alloy is aged at $160{ }^{\circ} \mathrm{C}$ for $60 \mathrm{~h}$.

\section{Discussion}

\subsection{Phase Identification}

The morphology of $\mathrm{Al}_{3}(\mathrm{Sc}, \mathrm{Zr}$ ) was reported to be pedallike or double semi-spheres coupling [5], and $\delta^{\prime}$ has a spherical shape or sometimes a bull-eye composite phase $\delta^{\prime} / \beta^{\prime}\left(\mathrm{Al}_{3} \mathrm{Zr}\right)$ [9]. The equilibrium phase $\delta$ tends to form 

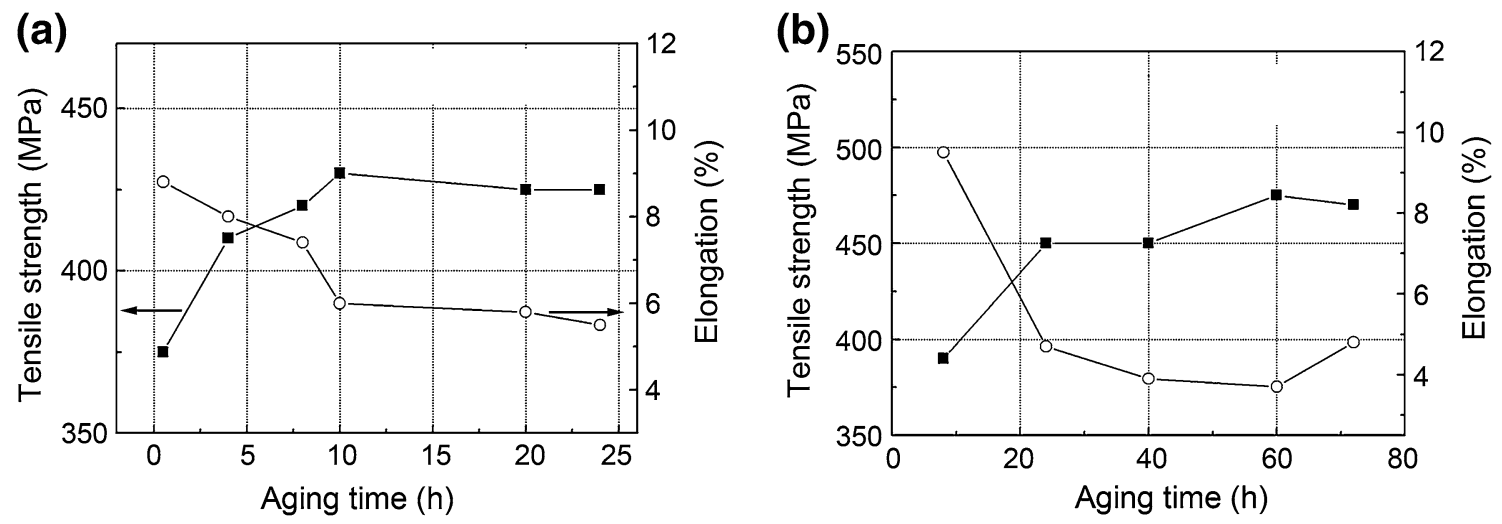

Fig. 2 Tensile strength and elongation as function of aging time at $190{ }^{\circ} \mathrm{C} \mathrm{a}, 160{ }^{\circ} \mathrm{C} \mathrm{b}$

under the over-aged condition and has different $\mathrm{Li}$ concentrations and crystal structure (NaT1-type bcc structure) compared with $\delta^{\prime}$ [4]. Needle-like T1 phase forms along the (111) plane of matrix. Meanwhile, the semi-coherent $\theta^{\prime}$ phase forms as the platelets or disks in (001) plane of matrix [3]. $\theta^{\prime \prime}$ phase also looks like disk, which is coherent with the matrix and has a smaller size than $\theta^{\prime}$ phase (about $30 \mathrm{~nm}$ in diameter).

Among all the precipitates, only the metastable phases $\left[\theta^{\prime \prime}, \theta^{\prime}, \delta^{\prime}\right.$ and $\left.\mathrm{Al}_{3}(\mathrm{Sc}, \mathrm{Zr})\right]$ and $\mathrm{T} 1$ phase are strengthening phases $[4,5]$. As the decomposition reactions are complicated in the alloy, there is a question that needed to be clarified: What sequence do these phases precipitate? In order to explain the variation in the aging hardening behaviors and tensile properties, the morphology and structure of precipitates during the aging treatment are systematically investigated.

\subsection{Microstructure Evolution at $190{ }^{\circ} \mathrm{C}$}

Figure 3 shows the SAED patterns taken along the $[110]_{\mathrm{Al}}$ zone axis of the samples aged at $190{ }^{\circ} \mathrm{C}$ for $30 \mathrm{~min}, 2 \mathrm{~h}$ and $10 \mathrm{~h}$, respectively. Figure $3 \mathrm{a}$ exhibits fundamental reflections and super lattice spots such as $\langle 010\rangle$ and $\langle-110\rangle$, which implies the formation of the $\mathrm{L}_{2}$ precipitates $\left[\mathrm{Al}_{3}\right.$ ( $\mathrm{Sc}, \mathrm{Zr}$ ), $\left.\beta^{\prime}, \delta^{\prime}\right]$ [15]. The reflections at $1 / 3\langle 220\rangle$ (in Fig. 3b, c) and streaks along the $\langle 111\rangle$ direction (in Fig. 3c) demonstrate the presence of $\mathrm{T} 1$ phase. It can be concluded that the $\mathrm{T} 1$ phase is formed when the aging time prolongs from $30 \mathrm{~min}$ to $2 \mathrm{~h}$. Furthermore, the spots arising from T1 phase become stronger when the alloy is in peak-aged state, in which the size of $\mathrm{T} 1$ phase becomes larger.

Figure 4 presents the microstructure evolution of the alloy during aging at $190{ }^{\circ} \mathrm{C}$. After aging for $30 \mathrm{~min}, \mathrm{Al}_{3}$ (Sc, $\mathrm{Zr}$ ) is a dominant phase in sight (Fig. 4a), which corresponds to the superlattice spots in Fig. 3a. As the aging time prolongs to $2 \mathrm{~h}, \delta^{\prime}, \theta^{\prime}$ and T1 precipitates could also be observed (Fig. $4 \mathrm{~b})$. At the peak-aged state $(10 \mathrm{~h})$, the fraction of $\theta^{\prime}$ and $\mathrm{T} 1$ increases and their sizes are much bigger (Fig. 4c). Meanwhile, the average size of $\delta^{\prime}$ grows to about $20 \mathrm{~nm}$ and some forms the bull-eye shape composites $\delta^{\prime} / \beta^{\prime}$ at the peak-aged state, indicating that $\delta^{\prime}$ precipitates envelop spherical $\beta^{\prime}$ precipitates [9]. As shown in Fig. $4 \mathrm{~d}$, over-aging results in the coarsening of $\mathrm{T} 1$ and $\theta^{\prime}$ phases and the presence of equilibrium phase $\delta$. It can be seen that $\mathrm{T} 1$ phase cuts through $\delta^{\prime}$ and $\delta$ (Fig. 4d),
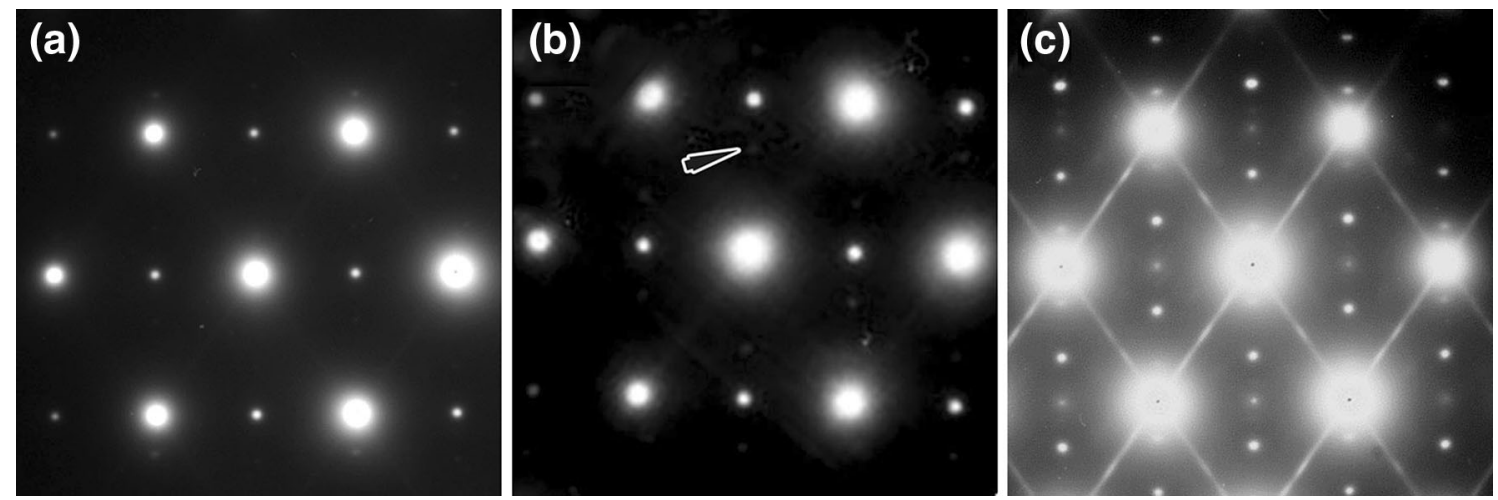

Fig. 3 SAED patterns (along $[110]_{\mathrm{Al}}$ ) of the samples aged at $190{ }^{\circ} \mathrm{C}$ for $30 \mathrm{~min} \mathbf{a}, 2 \mathrm{~h} \mathrm{~b}, 10 \mathrm{~h} \mathrm{c}$ 

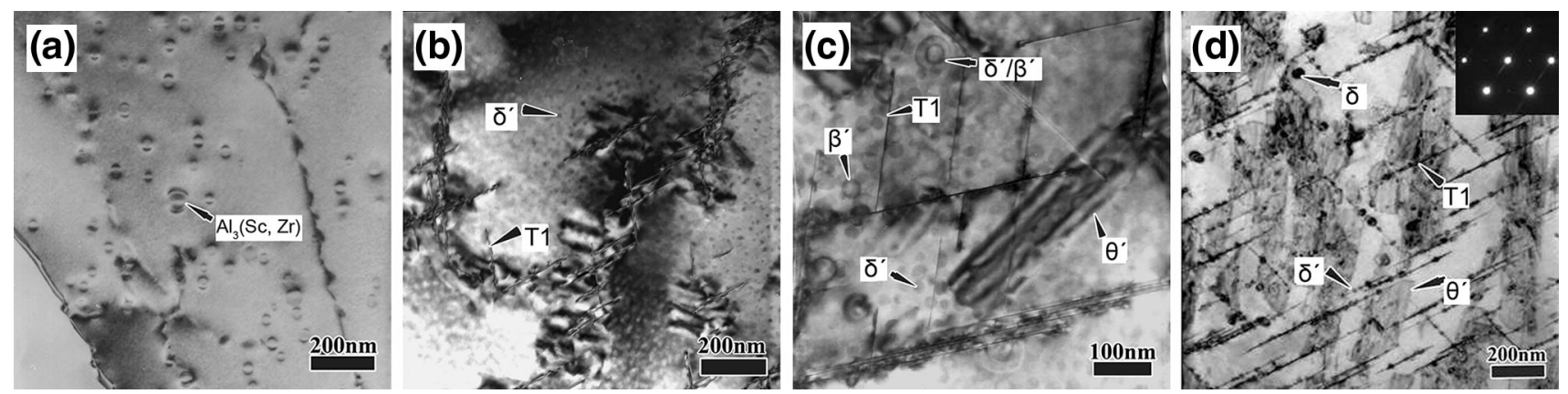

Fig. 4 TEM images (along $[110]_{\mathrm{Al}}$ ) of the samples aged at $190{ }^{\circ} \mathrm{C}$ for $30 \mathrm{~min} \mathbf{a}, 2 \mathrm{~h} \mathrm{~b}, 10 \mathrm{~h} \mathrm{c}, 20 \mathrm{~h} \mathrm{~d}$

suggesting that T1 phase is formed at the expense of the $\delta$ and $\delta^{\prime}$ precipitate. This phenomenon was observed by Tosten et al. [18].

\subsection{Microstructure Evolution at $160{ }^{\circ} \mathrm{C}$}

The microstructure evolution of the samples aged at $160{ }^{\circ} \mathrm{C}$ is revealed in Fig. 5. It can be concluded from Fig. 5 that, at $160{ }^{\circ} \mathrm{C}$, the aging process is similar to that at $190{ }^{\circ} \mathrm{C}: \mathrm{Al}_{3}(\mathrm{Sc}, \mathrm{Zr})$ and $\delta^{\prime}$ precipitate at the initial stage of aging, and then followed by the precipitation of $\theta^{\prime}$ and $\mathrm{T} 1$ phases. According to Figs. 4a, c and 5a, d, it can be concluded that the early rapid increase of the microhardness is caused by the formation of the $\mathrm{L}_{2}$ type precipitates of $\mathrm{Al}_{3}$
(Sc, $\mathrm{Zr}$ ) and $\delta^{\prime}$. The DF image (Fig. 5d) shows that the $\mathrm{Al}_{3}$ ( $\mathrm{Sc}, \mathrm{Zr}$ ) particles are cores of the bull-eye shape composites indicating that the $\delta^{\prime}$ also nucleates on $\mathrm{Al}_{3}(\mathrm{Sc}, \mathrm{Zr}$ ). With the aging prolong, more and more $\mathrm{T} 1$ precipitates are formed (Fig. 5a-c) because that $\mathrm{T} 1$ grows at the expense of $\delta^{\prime}$ [17], resulting in the reduced fraction of $\delta^{\prime}$ (Fig. 5d-f). As it is shown in Fig. 5c, the length of $\mathrm{T} 1$ phase ranges from 100 to $200 \mathrm{~nm}$ after aging at $160{ }^{\circ} \mathrm{C}$. However, when aged at $190{ }^{\circ} \mathrm{C}$, the size of $\mathrm{T} 1$ is much larger (about $400 \mathrm{~nm}$ long) (Fig. 4c), indicating a decreasing fraction of $\mathrm{T} 1$ phase. Considering the fact that the peak strength of $160{ }^{\circ} \mathrm{C}$ is higher, it could be concluded that the smaller and dispersive $\mathrm{T} 1$ precipitates are more effective in improving the tensile strength.
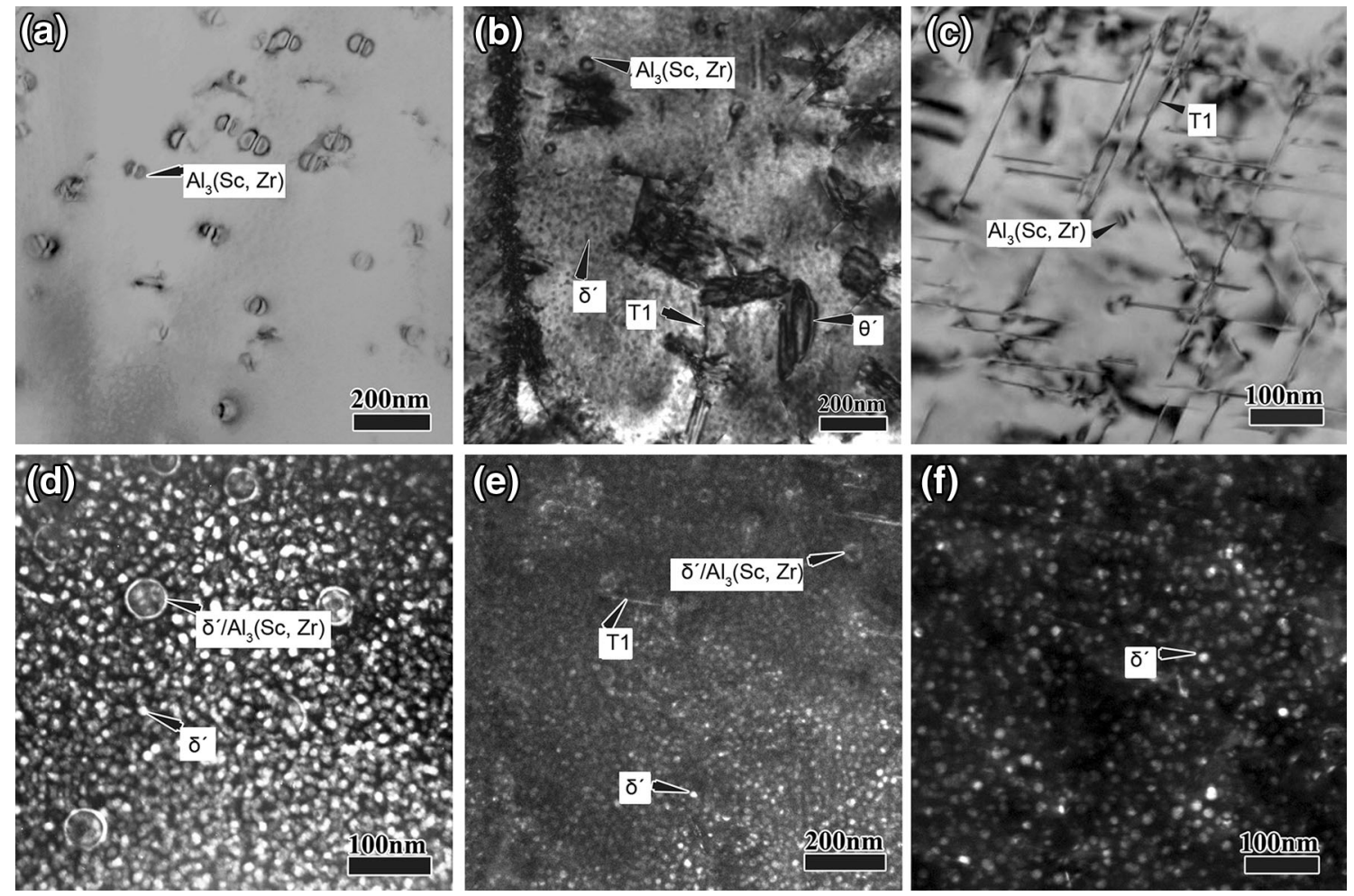

Fig. $5 \mathrm{BF}$ and DF images taken along $[110]_{\mathrm{Al}}$ of samples aged at $160{ }^{\circ} \mathrm{C}$ for different time: a, d $4 \mathrm{~h} ; \mathbf{b}, \mathbf{e} 24 \mathrm{~h} ; \mathbf{c}, \mathbf{f} 60 \mathrm{~h}$ 

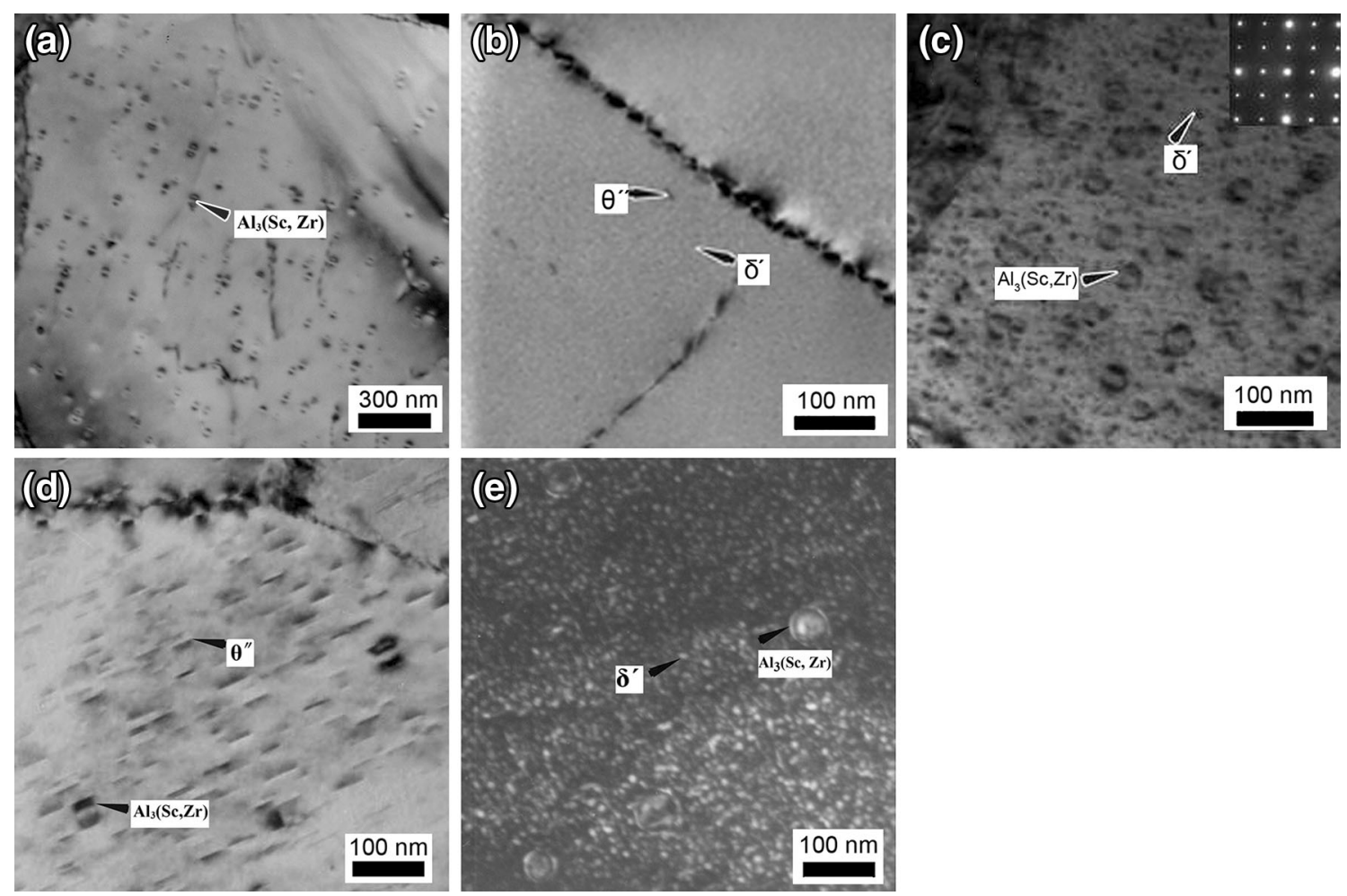

Fig. $6 \mathrm{BF}$ images taken along [100] $]_{\mathrm{Al}}$ of samples aged at $130{ }^{\circ} \mathrm{C}$ for $8 \mathrm{~h} \mathrm{a}, 24 \mathrm{~h} \mathrm{~b}, 72 \mathrm{~h} \mathrm{c}, 84 \mathrm{~h} \mathrm{~d}$, DF image taken along [100] $]_{\mathrm{Al}}$ of sample aged at $130{ }^{\circ} \mathrm{C}$ for $84 \mathrm{~h}$ e

Table 1 Summary of the features of the aging at different temperatures

\begin{tabular}{|c|c|c|c|}
\hline Temperature & Advantage & Disadvantage & Others \\
\hline $130{ }^{\circ} \mathrm{C}$ & $\begin{array}{l}\text { (1) High nucleation rate } \\
\text { (2) Smaller and more } \\
\text { dispersive precipitates }\end{array}$ & $\begin{array}{l}\text { (1) Precipitates are difficult to grow up } \\
\text { (2) T1 phase hardly shows up }\end{array}$ & $\delta^{\prime}$ and $\theta^{\prime \prime}$ precipitate separately \\
\hline 160 and $190{ }^{\circ} \mathrm{C}$ & $\begin{array}{l}\text { (1) Short peak-aging time } \\
\text { (2) Precipitates nucleate and } \\
\text { grow up easily and quickly }\end{array}$ & $\begin{array}{l}\text { (1) Precipitates are apt to have big size } \\
\text { (2) } \delta^{\prime} \text { phase is easily over-aged }\end{array}$ & $\begin{array}{l}\delta^{\prime} \text { appears earlier; } \theta^{\prime} \text { and } \mathrm{T} 1 \\
\text { come into being later; } \theta^{\prime \prime} \text { is } \\
\text { hardly seen }\end{array}$ \\
\hline
\end{tabular}

\subsection{Microstructure Evolution at $130{ }^{\circ} \mathrm{C}$}

The aging hardening curve of the alloy at $130{ }^{\circ} \mathrm{C}$ is quite different from that at 190 and $160{ }^{\circ} \mathrm{C}$. The microstructure evolution of the alloy at $130{ }^{\circ} \mathrm{C}$ is presented in Fig. 6. It could be seen that fine $\mathrm{Al}_{3}(\mathrm{Sc}, \mathrm{Zr})$ and $\delta^{\prime}$ phases are uniformly distributed in the matrix when aging within $24 \mathrm{~h}$ (Fig. 6a, b), which may be the response for the increase in the microhardness (see Fig. 1). This trend is similar to those after aging at 160 and $190{ }^{\circ} \mathrm{C}$. However, during the subsequent aging treated from $24 \mathrm{~h}$ (Fig. 6b) to $72 \mathrm{~h}$ (Fig. 6c), the size of $\delta^{\prime}$ precipitates increases and its density remains unchanged, and no T1 and $\theta^{\prime}$ phases are detected. As a result, the microhardness keeps steady during the transition stage. Figures $6 \mathrm{~d}$ and e reveal the distribution of the precipitates after aging for $84 \mathrm{~h}$, which leads to the second increase of microhardness in the aging hardening curve (see Fig. 1). Large amount of $\theta^{\prime \prime}$ phase with an average size of $20 \mathrm{~nm}$ can be observed in Fig. 6d, which contributes to the second increase of the microhardness.

The precipitation process is controlled by the diffusion rate of the solute atoms. The diffusion rate of $\mathrm{Cu}$ is slow at aging temperature of $130{ }^{\circ} \mathrm{C}$, and the $\mathrm{Cu}$ atoms are not as active as $\mathrm{Li}$ atoms. As a result, the precipitation of the phases $\left(\theta^{\prime \prime}, \theta^{\prime}\right.$ and $\mathrm{T} 1)$ containing $\mathrm{Cu}$, is strongly influenced. For example, no T1 and $\theta^{\prime}$ precipitates can be observed; second, there is a period of aging time (from 24 to $72 \mathrm{~h}$ ) between the precipitation of $\delta^{\prime}$ and $\theta^{\prime \prime}$, in other words, $\delta^{\prime}$ and $\theta^{\prime \prime}$ precipitate separately at $130{ }^{\circ} \mathrm{C}$. Transformation of the precipitation process results in a far delayed two-stage increase of the microhardness (Fig. 1). 


\subsection{Precipitation Behavior of Different Age Conditions}

The advantages and disadvantages of the three age conditions have been summarized in Table 1. At lower aging temperature $\left(130^{\circ} \mathrm{C}\right)$, the nucleation rate of the precipitates is high, and their distribution is uniform; however, the growth of some phases ( $\mathrm{T} 1$ and $\theta^{\prime}$ ) is restricted by the diffusion rate of $\mathrm{Cu}$. As the aging temperature rises to $190{ }^{\circ} \mathrm{C}$, the decomposition reactions occur in a shorter time, while the $\delta^{\prime}$ phase is easily over-aged. When the alloy is aged at $160{ }^{\circ} \mathrm{C}$, the $\mathrm{T} 1$ phase is dispersive, and the $\delta^{\prime}$ is relatively stable.

\section{Conclusions}

1. At higher aging temperature $\left(160\right.$ and $\left.190{ }^{\circ} \mathrm{C}\right), \delta^{\prime}$, T1 and $\theta^{\prime}$ precipitates tend to form altogether, which results in a combinative strengthening effect and a rapid increase of microhardness. When the alloy was aged at $130{ }^{\circ} \mathrm{C}, \mathrm{T} 1$ and $\theta^{\prime}$ phases are not formed, and $\delta^{\prime}$ and $\theta^{\prime \prime}$ phases are precipitated uniformly but separately, which leads to a far delayed two-stage increase of microhardness.

2. During aging, $\mathrm{Al}_{3}(\mathrm{Sc}, \mathrm{Zr})$ and $\delta^{\prime}$ precipitate at very early stage. T1 and $\theta^{\prime}$ phases form later than $\delta^{\prime} . \theta^{\prime \prime}$ does not appear under high temperature aging condition $\left(160,190^{\circ} \mathrm{C}\right)$, while $\mathrm{T} 1$ and $\theta^{\prime}$ are hardly seen when aged at $130{ }^{\circ} \mathrm{C}$.

3. $\mathrm{T} 1$ precipitates are the major strengthening phase in 1460 alloy. When aged at $160{ }^{\circ} \mathrm{C}$ for $60 \mathrm{~h}$, the distribution of $\mathrm{T} 1$ precipitates is dispersive and their size are smaller, which results in a preferable strength.

\section{References}

1. R. Rioja, Mater. Sci. Eng. A 257, 100 (1998)

2. P. Donnadieu, Y. Shao, F. De Geuser, G.A. Botton, S. Lazar, M. Cheynet, M. de Boissieu, A. Deschamps, Acta Mater. 59, 462 (2011)

3. P.C. Song, X.F. Li, W. Ding, J. Chen, Acta Metall. Sin. (Engl. Lett.) 27, 642 (2014)

4. H.Y. Li, Y. Tang, Z.D. Zeng, Z.Q. Zheng, F. Zheng, Mater. Sci. Eng. A 498, 314 (2008)

5. I. Gutierrez-Urrutia, J. Mater. Sci. 46, 3144 (2011)

6. Z.Q. Lin, J. Mater. 3, 10 (1992)

7. R.P. Sawtell, M.A. Hopkins, J. Mater. Trans. A 21, 421 (1990)

8. F.W. Gayle, F.H. Heubaum, J.R. Pickens, Scr. Metall. Mater. 24, 79 (1990)

9. B. Gault, F. de Geuser, L. Bourgeois, B.M. Gabble, S.P. Ringer, B.C. Muddle, Ultramicroscopy 111, 683 (2011)

10. R. Yoshimura, T.J. Konno, E. Abe, K. Hiraga, Acta Mater. 51, 4251 (2003)

11. N.E. Prasad, A.A. Gokhale, P.R. Rao, Sadhana Acad. Proc. Eng. Sci. 28, 209 (2003)

12. B.X. Liu, Y.C. Tan, Aerosp. Sci. Technol. 3, 49 (2001)

13. S. Ahmadi, H. Arabi, A. Shokuhfar, J. Mater. Sci. Technol. 26, 1078 (2010)

14. D.J. Waldron, W.F. Bozich, USA patent, US006074498A, (2000)

15. S. Ahmadi, H. Arabi, A. Shokuhfar, J. Alloys Compd. 484, 90 (2009)

16. A.K. Shukla, W.A. Baeslack, Scr. Mater. 56, 513 (2007)

17. J. Ma, D.S. Yan, L.J. Rong, Y.Y. Li, Prog. Nat. Sci Mater. Int. 24, 13 (2014)

18. M.H. Tosten, A.K. Vasudevan, P.R. Howell, Metall. Trans. A 19, 51 (1988) 